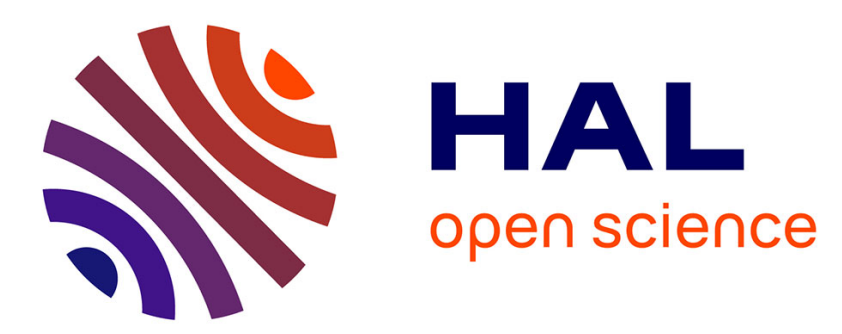

\title{
Complex links between dietary lipids, endogenous endotoxins and metabolic inflammation.
}

Fabienne Laugerette, Cécile Vors, Noël Peretti, Marie-Caroline Michalski

\section{To cite this version:}

Fabienne Laugerette, Cécile Vors, Noël Peretti, Marie-Caroline Michalski. Complex links between dietary lipids, endogenous endotoxins and metabolic inflammation.. Biochimie, 2011, 93 (1), pp.3945. 10.1016/j.biochi.2010.04.016 . inserm-00486698

\section{HAL Id: inserm-00486698 https://www.hal.inserm.fr/inserm-00486698}

Submitted on 26 May 2010

HAL is a multi-disciplinary open access archive for the deposit and dissemination of scientific research documents, whether they are published or not. The documents may come from teaching and research institutions in France or abroad, or from public or private research centers.
L'archive ouverte pluridisciplinaire HAL, est destinée au dépôt et à la diffusion de documents scientifiques de niveau recherche, publiés ou non, émanant des établissements d'enseignement et de recherche français ou étrangers, des laboratoires publics ou privés. 
Mini-review and metabolic inflammation

Fabienne Laugerette, ${ }^{1,2, \dagger}$ Cécile Vors, ${ }^{3,4, \dagger}$ Noël Peretti ${ }^{2,6}$ and Marie-Caroline Michalski ${ }^{4,5 *}$

$11{ }^{\dagger} F L$ and $C V$ contributed equally to the work.

${ }^{1}$ Universite de Lyon, F-69100 VILLEURBANNE

${ }^{2}$ INSERM, U870, RMND, F-69621 VILLEURBANNE

${ }^{3}$ INSA-Lyon, IMBL, F-69621 VILLEURBANNE

${ }^{4}$ INRA, UMR 1235, RMND, F-69921 OULLINS

${ }^{5}$ CRNH Rhône-Alpes, F-69921 OULLINS

${ }^{6}$ Hospices Civils de Lyon, Hopitâl Femme Mère Enfant, F-69500 BRON

*Corresponding author:

UMR Régulations Métaboliques Nutrition et Diabètes, IMBL Building, INSA-Lyon,

Tel : +33472438112.

Fax : + 33472438524 .

marie-caroline.michalski@insa-lyon.fr

\section{$\underline{\text { Abstract }}$}

Metabolic diseases such as obesity are characterized by a subclinical inflammatory state that contributes to the development of insulin resistance and atherosclerosis. Recent reports also indicate that (i) there are alterations of the intestinal microbiota in metabolic diseases and (ii) absorption of endogenous endotoxins (namely lipopolysaccharides, LPS) can occur, particularly during the digestion of lipids. The aim of the present review is to highlight recently gained knowledge regarding the links between high fat diets, lipid digestion, intestinal microbiota and metabolic endotoxemia \& 


\section{Introduction}

Nowadays, obesity outbreak is an important health problem due to its association with metabolic disorders such as type 2 diabetes, hyperlipidemia and hypertension. These metabolic diseases resulting of genetic, environmental and nutritional factors are characterized by a subclinical inflammatory state that contributes to the development of insulin resistance and atherosclerosis $[1,2]$. Although the markers of chronic inflammation such as C-reactive protein predictive of the development of atherosclerosis are clearly established, the factors responsible for the initiation and maintenance of the chronic inflammation remain to be elucidated [3]. It was however noticed very recently that (i) there are alterations of the intestinal microbiota in metabolic diseases and (ii) absorption of endotoxins (namely lipopolysaccharides, LPS) can occur $[4,5]$. Endotoxins, which are components of gram negative bacteria cell wall, can appear in blood circulation from intestinal microbiota via translocation [6].

New evidence supports the idea of a link between high fat diet and the release of endotoxins in plasma of mice and humans $[4,7,8]$. The different results suggest that a chronic fat-rich diet could result in increased endotoxemia and low-grade inflammation due to the repeated endotoxin absorption from the gut during the digestion of lipids, which in turn could increase the risk of insulin resistance and atherosclerosis. Such endoxemia can be defined as "metabolic endotoxemia", in contrast with other types of endotoxemia originating from exogenous bacterial infection or sepsis. Moreover, we recently evidenced that the structure of lipids in food could be one of the determinants of LPS absorption during fat digestion in non-pathological conditions [9].

The present review will thus discuss the different issues relating metabolic inflammation, intestinal microbiota, endogenous endotoxin absorption and the possible modulation by lipid structure.

\section{Inflammation in metabolic diseases}

The low-grade inflammation is a common feature in the patho-physiology of obesity and type 2 diabetes [3, 10, 11]. Moreover, such inflammation increases the risk of insulin resistance and atherosclerosis [12-16]. The inflammatory response is characterized by the increase of proinflammatory cytokines as interleukin-6 (Il-6) and tumor necrosis factor- $\alpha$ (TNF- $\alpha$ ) in plasma [17]. Nappo et al. have reported that a high-fat meal is able to enhance these inflammatory cytokines contrary to a high carbohydrate meal [18]. It has been shown that butter and walnuts elicit postprandial activation of nuclear transcription factor kappa B (NFkB) in the peripheral blood monuclear cells from healthy subjects [19]. Moreover, patients suffering from coronary diseases and submitted to a high fat meal present an increase of IL-6 [20]. A recent study leads by

35 Tulk \& Robinson reports that by increasing the n-3 PUFA content of a high-saturated fat meal in

$$
\text { p. } 2 / 15
$$


men with metabolic syndrome, inflammatory responses were not modified [21]. More recently, Magné et al. demonstrated a possible implication of visceral adipose tissue in the postprandial low-grade inflammation after a high-saturated fat meal in healthy rats, with a transient activation of NFkB [22]. Moreover, the pathogenesis of insulin and leptin resistance associated with the intake of high fat high carbohydrate meals can be mediated by an increase in SOCS-3 (suppressor of cytokine signaling-3) in mononuclear cells after such meals, which is concomitant with increased markers of inflammation [23].

However, it is still difficult to understand the mechanisms by which a high-fat diet promotes the low-grade inflammation. In this respect, new studies suggest that the quality of intestinal microbiota might be involved.

\section{Alterations of intestinal microbiota in metabolic diseases}

The intestinal microbiota, which is species specific and innate, may though be modified in some conditions [18]. Moreover, Turnbaugh et al. suggested that intestinal microbiota might affect energy balance [24]. A high fat diet in mother rats can influence the gut microbiota in rat pups and increase their adiposity and body weight [25]. Conversely, germ-free animals are protected from diet-induced obesity by increasing fatty acid metabolism [26, 27].

Several recent studies report alterations in the composition of intestinal microbiota in the course of obesity, with differences in quantity and proportion of two dominant gut bacteria: Bacteroidetes and Firmicutes [28]. For example, ob/ob mice have a $50 \%$ reduction on Bacteroidetes and a proportional increase in Firmicutes in comparison with lean mice [29]. In human, the microbiota appears to be different between lean and obese subjects $[24,30]$ with a decrease of Gram negative bacteria of the phylum Bacteroidetes in obese subject [31]. However, Duncan et al. did not observe such differences in Bacteroidetes/Firmicutes between lean and obese subjects [32], while Zhang et al. report that obese subjects present greater amounts of Bacteroidetes in their microbiota compared to lean ones [33]. Therefore, the relative content of each bacterial species in different pathophysiological conditions remains a subject of debate.

Such alterations of the gut microbiota in obesity are important to characterize because they could trigger endogenous endotoxin (LPS) absorption from microbiota Gram negative bacteria. Indeed, recent data report the presence of low-doses of these pro-inflammatory LPS in the plasma of obese humans [10], in type 2 diabetes [34] or in patients with Crohn disease [35]. Moreover, a study by Cani et al. has shown that antibiotic treatment modifies the gut microbiota, reduces metabolic endotoxemia and the cecal content of LPS in both high fat-fed and $o b / o b$ mice [5]. The quality of intestinal microbiota was correlated with intestinal barrier integrity, whose loss may lead to pro-inflammatory endotoxemia $[36,37]$. It was recently shown in healthy humans that the 
administration of probiotic-containing yoghurt may improve the gut barrier function, decreasing endotoxin release and reducing low-grade chronic inflammation [38]. Prebiotics such as oligofructose can also increase Bifidobacteria in mice gut, which is associated with decreased endotoxemia [39].

Consequently, the intestinal microbiota can be under the influence of the diet, which in turn may increase the intestinal absorption of LPS that can play a role in the low-grade-inflammation observed in obesity.

\section{Proinflammatory properties of endotoxins from Gram negative bacteria (LPS)}

LPS, which represent about $80 \%$ of the cell wall mass of Gram negative bacteria, are toxic compounds localized on the surface of bacterial cells as a part of the outer membrane. They are constituted by an antigen-O specific chain, by a core region which represents a heterooligosaccharide, and by a lipid A region highly conserved and representing the toxic part of the LPS [40] (Figure 1A).

In pathological conditions such as infection of chronic diseases in humans, Gram negative bacteria can colonize the oral cavity and respiratory tract; they generate LPS that can lead to sepsis [41]. During a bacterial infection, LPS concentration in blood (so-called endotoxemia, normally low in healthy humans) is increased and is able to trigger the production of proinflammatory factors as cytokines $[42,43]$. For example, the average endotoxin concentration was reported to be higher in peritoneal dyalisis patients that present systemic inflammation $(0.44$ $\pm 0.18 \mathrm{EU} / \mathrm{ml})$, compared to healthy controls $(0.013 \pm 0.007 \mathrm{EU} / \mathrm{ml}, \mathrm{P}<0.0001)$ [44].

Indeed, LPS are taken up by the Lipopolysaccharide Binding-Protein (LBP) a $65 \mathrm{kDa}$ protein produced by the liver and present in the blood at concentrations of approximately $2-20 \mu \mathrm{g} / \mathrm{mL}$ [45], and transferred to the glycophosphatidylinositol-linked receptor CD14 (cluster of differentiation-14) [46], expressed on the plasma membrane of various cell types, like monocytes, macrophages [47] or human intestinal epithelial cell lines [48]. Besides this membrane-bound (mCD14) state, CD14 is also found in a circulating soluble (sCD14) form [49], increasing during septic diseases [50, 51]. Moreover, sCD14 is involved in the bioactivity of circulating endotoxin, and can be considered as a potent marker of endotoxin in plasma [52]. Both forms of CD14 are able to bind the complex LPS-LBP and mediate signal transduction, including the activation of the transcription factor nuclear factor-қB (NFқB) via a toll like receptor-4 (TLR4) dependant way associate with MD-2 [53]. This signalling cascade results in the release of pro-inflammatory cytokines such as Interleukin (IL)-6, or tumor necrosis factor alpha (TNF- $\alpha$ ) [54], maintaining the 
1 low-grade inflammation (Figure 1B). These different receptors are also present on the surface of

2 intestinal cells. Indeed, intestinal cells are able to produce, express and release molecules of LBP,

3 CD14 and TLR4. The same series of events described above concerning immunity cells also take

4 place at intestinal level. Epithelial cells interact with LPS, and so, are active in intestinal immune

5 system [55].

6 However, in the case of septic shock, LBP is able to transfer LPS to plasma lipoproteins like HDL and chylomicrons, which neutralize endotoxin activity [56-59]. This neutralization results from the binding of the lipoproteins to their receptors, particularly on the liver, inducing increased biliary secretion of LPS $[60,61]$. In addition to LBP, the phospholipid transfer protein (PLTP) implicated in the development of atherosclerosis [62] is able to link LPS and to detoxify the organism during septic shock $[63,64]$.

However, in non-pathological conditions, the healthy human body also contains numerous endogenous bacteria $\left(\sim 10^{14}\right)[6]$. In this case, Gram negative bacteria reside as a majority in the gut in which they constitute, together with Gram positive bacteria, the intestinal microbiota. Intestinal absorption of endogenous LPS from this microbiota would result in the same proinflammatory mechanisms as described above, though to a much lesser extent: low-grade inflammation or so-called metabolic inflammation as observed in obesity.

\section{Links between high fat diets, inflammation and endotoxemia}

Extrinsic factors such as the diet can affect the inflammatory response to exogenous LPS. For example, mice submitted to a high saturated fat and cholesterol diet increase their sensitivity to LPS injection [65]. However, very recent studies also support the concept that dietary fats can induce absorption of endogenous LPS from the intestinal microbiota and subsequent inflammatory response.

The pioneering article by Cani et al. (2007) reported that a four-week high fat diet in mice (72\% energy as fat) increases plasma endotoxin levels (endotoxemia) in comparison with a control diet, and that chronic low-dose infusion of LPS leads to weight gain and insulin resistance [4]. In turn CD14-KO mice resisted to increased weight gain, endotoxemia and insulin resistance induced by a high fat diet [4]. Importantly, Shi et al. have also shown that TLR4-KO mice are protected from NFkB-induced inflammation and development of insulin resistance [66]. Both works thus show a link between innate immunity and lipid-induced insulin resistance. Moreover, the increase in plasma LPS is lower when mice are submitted to a diet containing 35\% energy as fat compared with mice fed a high-fat diet [7]. In humans, Amar et al. found a link between food intake and plasma endotoxin, with a positive correlation between energy intake and endotoxemia [7]. 
1 On an acute basis, Erridge et al. showed in humans that an acute high fat bolus (50 $\mathrm{g}$ butter on toast) was sufficient to promote a transient increase in endotoxemia, $30 \mathrm{~min}$ after ingestion, in lean to obese occasional smokers [8]. Because these authors considered that smoking could contribute to elevation of plasma endotoxin via the absorption of LPS by lung [67], they examined endotoxemia for 4 hours in men receiving no meal, a high-fat meal, no meal and 3 cigarettes, or a high-fat meal and 3 cigarettes [8]. Fat was found to be the only significant parameter impacting on postprandial endotoxemia [8]. Consistently, Ghoshal et al. show in mice that forced feeding with triolein leads to an increase of endotoxemia after 90 minutes [68]. Conversely, feeding with tributyrin or chemically preventing chylomicron secretion blunted postprandial endotoxemia [68]. Most recently, we have shown in healthy non-smoking humans that the digestion of a mixed breakfast, containing various types of lipids (animal, vegetal) in emulsified and non-emulsified forms, results in a transient elevation of endotoxin in plasma and an increase of sCD14 [9]. This can explain the significant peak of inflammatory cytokine IL-6 that we observed $2 \mathrm{~h}$ after the mixed meal (Figure 2A). Moreover, LPS appeared to be partly transported by chylomicrons (Figure 2A), as observed by endotoxemia measurements and LPS immunogold labelling on purified chylomicrons [9].

Altogether, these results show that high fat diet can result in increased endotoxemia, which in turn could be triggered by repeated ingestions of single high fat meals. Indeed, lipid digestion and chylomicrons secretion can promote intestinal absorption of LPS from gut microbiota [9, 68], which could contribute to postprandial inflammatory responses $[69,70]$ and thus to the onset and maintenance of chronic low-grade inflammation.

6. New insights: where dietary fat properties and lipid absorption kinetics might impact on endotoxemia and inflammation

Elevated postprandial lipemia, due to postprandial chylomicron concentration, is known to have a deleterious impact on cardiovascular risk [71]. Particularly, new interest has recently arised in the literature regarding the metabolic importance of the kinetics of lipid absorption during digestion, which can be modulated by dietary fat structure $[72,73]$. In food products, most fatty acids are esterified in the form of triacylglycerols (TAG) that are digested in the stomach and in the small intestine through the action of specific lipases [74-76]. After the pancreatic lipolysis, free fatty acids and 2-monoacylglycerols are released, which are mainly absorbed by enterocytes. In the latter, lipolysis products are re-esterified as TAG, secreted into lymph and further released in the bloodstream in chylomicrons [74, 77].

The recent findings about postprandial endotoxemia and inflammation suggest a new role of the lipid digestion/chylomicron secretion phase, in promoting an immune response. Very recently, 
we have shown that the postprandial lipemia of rats was increased when fed a fine emulsion of sunflower oil with lecithin as emulsifier, compared to unemulsified sunflower oil [9]. This finding was consistent with another recent report in humans showing that the absorption of $n-3$ PUFA was higher from an emulsion than from the originate oil [78]. Most importantly, our results show that postprandial endotoxemia was increased after emulsion vs oil feeding, with AUC of LPS being correlated with AUC of TAG during digestion (Figure 2B, [9]). This correlation appears to be due to the role of chylomicrons in postprandial LPS transport $[9,68]$.

Now, it appears that the kinetics of postprandial lipemia and chylomicron secretion can be modified by dietary fat properties. Regarding fatty acid composition of dietary fat, Mekki et al. observed that butter in a meal resulted in (i) lower postprandial lipemia and chylomicron accumulation and (ii) smaller chylomicrons, than emulsified vegetable oil [79]. Regarding TAG molecular structure, dietary fats that contain mostly SFA at the $s n-2$ position of their TAG are reported to induce a higher and more prolonged postprandial lipemia [80]. Moreover, obese subjects can be more sensitive than lean ones regarding the modulation of postprandial lipemia by different TAG structures [81]. In general, long chain saturated fatty acids esterified to the $s n-1$ and $s n-3$ positions are less prone to be absorbed, due to their possible saponification as calcium soaps in the gastrointestinal tract that are excreted in stools [82-84]. Moreover, long chain saturated fatty acids present a higher solid proportion (so-called solid fat content, SFC) at $37^{\circ} \mathrm{C}$, which is reported to play an important role in limiting fat absorption $[85,86]$, especially in obese humans [81]. Some studies have also shown that differently emulsified lipids [87-90] and differently structured dairy products [91-95] result in different lipolysis and lipemia profiles, as previously reviewed [72, 96, 97]. We may thus wonder whether the biochemical and physicochemical properties of dietary fats could contribute to modulate LPS absorption during digestion, due to their effects on overall lipid absorption and chylomicron secretion.

In induced septic endotoxemia in animal models, the composition of dietary lipids was reported to affect inflammatory response and even death outcomes. For example in mice, it was shown, that a high saturated fat and cholesterol diet increased the sensitivity of mice to LPS, and the release of Il-6 and TNF- $\alpha$ [65]. Rats fed medium-chain TAG during 1 week presented a higher survival score and lower liver alterations after intraveinous infusion of a dose of LPS than their counterparts fed with corn oil presenting $100 \%$ death and acute liver alterations by infiltration \& activation of Küpffer cells [98]. During digestion, short- and medium chain fatty acids are absorbed directly by the portal vein to be oriented towards $\beta$-oxidation in the liver [74, 99]. Moreover, other recent results in rats show that medium chain TAG would protect against lipotoxicity and insulin resistance induced by high fat diet, compared to long chain saturated TAG that are usually reported to be deleterious [100]. Dietary phospholipids may also present 
1 nutritional benefits in the regulation of lipemia and chronic metabolic outcomes in the context of 2 high fat diets $[72,101]$.

3 Consequently, choosing adapted molecular lipid fomulations (fatty acid profile, PL vs TAG) and modifying the kinetics of lipid absorption and chylomicron secretion can be possible strategies to reduce postprandial endotoxin absorption and/or the metabolic consequences regarding low-grade inflammation (Figure 3).

\section{Conclusion}

The relationship between fat-rich diets and endotoxemia is an emerging concept, which could explain the onset and maintenance of the subclinical inflammatory state that enhances the development of insulin resistance. Recent results support the concept that the digestion of dispersed dietary lipids can enhance absorption of endogenous endotoxins. The long-term consequences of such postprandial endotoxemia in the context of high fat diets in humans, and the underlying mechanisms, remain to be further explored. Moreover, adapted lipid formulations and their physical structuration can change both the extent and kinetics of postprandial endotoxemia. Therefore, optimizing the quantity, composition, physicochemical properties and emulsification state of dietary fats can be possible strategies to limit postprandial endotoxemia, with the aim of preventing low-grade inflammation. In the current context of obesity and cardiovascular disease outbreak, the links between dietary lipid properties, inflammation and interactions with intestinal microbiota appear to be complex, thus justifying the need for interdisciplinary studies in the 21 future.

\section{Acknowledgements}

Fabienne Laugerette acknowledges grants from Institut Benjamin Delessert and Société Française de Nutrition. Cécile Vors is a recipient of doctoral grand from INRA \& CNIEL. Marie-Caroline Michalski acknowledges a grant from ALFEDIAM. 


\section{References}

[1] C. Bouchard, Current understanding of the etiology of obesity: genetic and nongenetic factors, The American journal of clinical nutrition 53 (1991) 1561S-1565S.

[2] S.U. Raymond, S. Leeder, H.M. Greenberg, Obesity and cardiovascular disease in developing countries: a growing problem and an economic threat, Current opinion in clinical nutrition and metabolic care 9 (2006) 111-116.

[3] R. Ross, Atherosclerosis is an inflammatory disease, Am Heart J 138 (1999) S419-420.

[4] P.D. Cani, J. Amar, M.A. Iglesias, M. Poggi, C. Knauf, D. Bastelica, A.M. Neyrinck, F. Fava, K.M. Tuohy, C. Chabo, A. Waget, E. Delmee, B. Cousin, T. Sulpice, B. Chamontin, J. Ferrieres, J.F. Tanti, G.R. Gibson, L. Casteilla, N.M. Delzenne, M.C. Alessi, R. Burcelin, Metabolic endotoxemia initiates obesity and insulin resistance, Diabetes 56 (2007) 1761-1772.

[5] P.D. Cani, R. Bibiloni, C. Knauf, A. Waget, A.M. Neyrinck, N.M. Delzenne, R. Burcelin, Changes in gut microbiota control metabolic endotoxemia-induced inflammation in high-fat dietinduced obesity and diabetes in mice, Diabetes 57 (2008) 1470-1481.

[6] R.D. Berg, The indigenous gastrointestinal microflora, Trends in Microbiology 4 (1996) 430-435.

[7] J. Amar, R. Burcelin, J.B. Ruidavets, P.D. Cani, J. Fauvel, M.C. Alessi, B. Chamontin, J. Ferrieres, Energy intake is associated with endotoxemia in apparently healthy men, Am $\mathrm{J}$ Clin Nutr 87 (2008) 1219-1223.

[8] C. Erridge, T. Attina, C.M. Spickett, D.J. Webb, A high-fat meal induces low-grade endotoxemia: evidence of a novel mechanism of postprandial inflammation, American Journal of Clinical Nutrition 86 (2007) 1286-1292.

[9] F. Laugerette, C. Vors, A. Geloen, M.A. Chauvin, C. Soulage, S. Lambert-Porcheron, N. Peretti, M. Alligier, R. Burcelin, M. Laville, H. Vidal, M.C. Michalski, Emulsified lipids increase endotoxemia: possible role in early postprandial low-grade inflammation, Journal of Nutritional Biochemistry doi:10.1016/j.jnutbio.2009.11.011 (2010).

[10] P. Libby, P.M. Ridker, A. Maseri, Inflammation and atherosclerosis, Circulation 105 (2002) 1135-1143.

[11] A.S. Greenberg, M.S. Obin, Obesity and the role of adipose tissue in inflammation and metabolism, The American journal of clinical nutrition 83 (2006) 461S-465S.

[12] R. Ross, The pathogenesis of atherosclerosis: a perspective for the 1990s, Nature 362 (1993) 801-809.

[13] P. Libby, Inflammation in atherosclerosis, Nature 420 (2002) 868-874.

[14] S.E. Shoelson, L. Herrero, A. Naaz, Obesity, inflammation, and insulin resistance, Gastroenterology 132 (2007) 2169-2180.

[15] G. Tarantino, P. Colicchio, P. Conca, C. Finelli, M.N.D. Di Minno, M. Tarantino, D. Capone, F. Pasanisi, Young adult obese subjects with and without insulin resistance: what is the role of chronic inflammation and how to weigh it non-invasively?, Journal of InflammationLondon 6 (2009) -.

[16] K. Park, M. Steffes, D.H. Lee, J.H. Himes, D.R. Jacobs, Association of inflammation with worsening HOMA-insulin resistance, Diabetologia 52 (2009) 2337-2344.

[17] G.C. Burdge, P.C. Calder, Plasma cytokine response during the postprandial period: a potential causal process in vascular disease?, The British journal of nutrition 93 (2005) 3-9.

[18] F. Nappo, K. Esposito, M. Cioffi, G. Giugliano, A.M. Molinari, G. Paolisso, R. Marfella, D. Giugliano, Postprandial endothelial activation in healthy subjects and in type 2 diabetic patients: role of fat and carbohydrate meals, Journal of the American College of Cardiology 39 (2002) 1145-1150.

[19] C. Bellido, J. Lopez-Miranda, L.M. Blanco-Colio, P. Perez-Martinez, F.J. Muriana, J.L. Martin-Ventura, C. Marin, P. Gomez, F. Fuentes, J. Egido, F. Perez-Jimenez, Butter and walnuts, but not olive oil, elicit postprandial activation of nuclear transcription factor kappaB in peripheral 
blood mononuclear cells from healthy men, The American journal of clinical nutrition 80 (2004) 1487-1491.

[20] P. Lundman, S. Boquist, A. Samnegard, M. Bennermo, C. Held, C.G. Ericsson, A. Silveira, A. Hamsten, P. Tornvall, A high-fat meal is accompanied by increased plasma interleukin-6 concentrations, Nutr Metab Cardiovasc Dis 17 (2007) 195-202.

[21] H.M. Tulk, L.E. Robinson, Modifying the $n-6 / n-3$ polyunsaturated fatty acid ratio of a high-saturated fat challenge does not acutely attenuate postprandial changes in inflammatory markers in men with metabolic syndrome, Metabolism: clinical and experimental 58 (2009) 17091716.

[22] J. Magne, F. Mariotti, R. Fischer, V. Mathe, D. Tome, J.F. Huneau, Early postprandial low-grade inflammation after high-fat meal in healthy rats: possible involvement of visceral adipose tissue, The Journal of nutritional biochemistry (2009).

[23] H. Ghanim, S. Abuaysheh, C.L. Sia, K. Korzeniewski, A. Chaudhuri, J.M. FernandezReal, P. Dandona, Increase in Plasma Endotoxin Concentrations and the Expression of Toll-like Receptors and Suppressor of Cytokine Signaling-3 in Mononuclear Cells After a High-Fat, HighCarbohydrate Meal Implications for insulin resistance, Diabetes Care 32 (2009) 2281-2287.

[24] P.J. Turnbaugh, R.E. Ley, M.A. Mahowald, V. Magrini, E.R. Mardis, J.I. Gordon, An obesity-associated gut microbiome with increased capacity for energy harvest, Nature 444 (2006) 1027-1031.

[25] S. Mozes, D. Bujnakova, Z. Sefcikova, V. Kmet, Developmental changes of gut microflora and enzyme activity in rat pups exposed to fat-rich diet, Obesity (Silver Spring, Md 16 (2008) 2610-2615.

[26] F. Backhed, R.E. Ley, J.L. Sonnenburg, D.A. Peterson, J.I. Gordon, Host-bacterial mutualism in the human intestine, Science (New York, N.Y 307 (2005) 1915-1920.

[27] F. Backhed, H. Ding, T. Wang, L.V. Hooper, G.Y. Koh, A. Nagy, C.F. Semenkovich, J.I. Gordon, The gut microbiota as an environmental factor that regulates fat storage, Proceedings of the National Academy of Sciences of the United States of America 101 (2004) 15718-15723.

[28] R. Burcelin, E. Luche, M. Serino, J. Amar, The gut microbiota ecology: a new opportunity for the treatment of metabolic diseases?, Front Biosci 14 (2009) 5107-5117.

[29] R.E. Ley, F. Backhed, P. Turnbaugh, C.A. Lozupone, R.D. Knight, J.I. Gordon, Obesity alters gut microbial ecology, Proceedings of the National Academy of Sciences of the United States of America 102 (2005) 11070-11075.

[30] M. Bajzer, R.J. Seeley, Physiology: obesity and gut flora, Nature 444 (2006) 1009-1010.

[31] R.E. Ley, P.J. Turnbaugh, S. Klein, J.I. Gordon, Microbial ecology - Human gut microbes associated with obesity, Nature 444 (2006) 1022-1023.

[32] S.H. Duncan, G.E. Lobley, G. Holtrop, J. Ince, A.M. Johnstone, P. Louis, H.J. Flint, Human colonic microbiota associated with diet, obesity and weight loss, Int J Obes (Lond) 32 (2008) 1720-1724.

[33] H. Zhang, J.K. DiBaise, A. Zuccolo, D. Kudrna, M. Braidotti, Y. Yu, P. Parameswaran, M.D. Crowell, R. Wing, B.E. Rittmann, R. Krajmalnik-Brown, Human gut microbiota in obesity and after gastric bypass, Proceedings of the National Academy of Sciences of the United States of America 106 (2009) 2365-2370.

[34] S.J. Creely, P.G. McTernan, C.M. Kusminski, M. Fisher, N.F. Da Silva, M. Khanolkar, M. Evans, A.L. Harte, S. Kumar, Lipopolysaccharide activates an innate immune system response in human adipose tissue in obesity and type 2 diabetes, American journal of physiology 292 (2007) E740-747.

[35] O. Pastor Rojo, A. Lopez San Roman, E. Albeniz Arbizu, A. de la Hera Martinez, E. Ripoll Sevillano, A. Albillos Martinez, Serum lipopolysaccharide-binding protein in endotoxemic patients with inflammatory bowel disease, Inflammatory bowel diseases 13 (2007) 269-277.

[36] P.D. Cani, N.M. Delzenne, Interplay between obesity and associated metabolic disorders: new insights into the gut microbiota, Curr Opin Pharmacol 9 (2009) 737-743. 
[37] P.D. Cani, S. Possemiers, T. Van de Wiele, Y. Guiot, A. Everard, O. Rottier, L. Geurts, D. Naslain, A. Neyrinck, D.M. Lambert, G.G. Muccioli, N.M. Delzenne, Changes in gut microbiota control inflammation in obese mice through a mechanism involving GLP-2-driven improvement of gut permeability, Gut 58 (2009) 1091-1103.

[38] E.J. Schiffrin, A. Parlesak, C. Bode, J.C. Bode, M.A. van't Hof, D. Grathwohl, Y. Guigoz, Probiotic yogurt in the elderly with intestinal bacterial overgrowth: endotoxaemia and innate immune functions, The British journal of nutrition 101 (2009) 961-966.

[39] P.D. Cani, A.M. Neyrinck, F. Fava, C. Knauf, R.G. Burcelin, K.M. Tuohy, G.R. Gibson, N.M. Delzenne, Selective increases of bifidobacteria in gut microflora improve high-fat-dietinduced diabetes in mice through a mechanism associated with endotoxaemia, Diabetologia 50 (2007) 2374-2383.

[40] M.J. Osborn, S.M. Rosen, L. Rothfield, L.D. Zeleznick, B.L. Horecker, Lipopolysaccharide of the Gram-Negative Cell Wall, Science 145 (1964) 783-789.

[41] L.L. Stoll, G.M. Denning, N.L. Weintraub, Potential role of endotoxin as a proinflammatory mediator of atherosclerosis, Arterioscler Thromb Vasc Biol 24 (2004) 22272236.

[42] T. Goto, S. Eden, G. Nordenstam, V. Sundh, C. Svanborg-Eden, I. Mattsby-Baltzer, Endotoxin levels in sera of elderly individuals, Clin Diagn Lab Immunol 1 (1994) 684-688.

[43] J.C. Marshall, Lipopolysaccharide: an endotoxin or an exogenous hormone?, Clin Infect Dis 41 Suppl 7 (2005) S470-480.

[44] C.C. Szeto, B.C. Kwan, K.M. Chow, K.B. Lai, K.Y. Chung, C.B. Leung, P.K. Li, Endotoxemia is related to systemic inflammation and atherosclerosis in peritoneal dialysis patients, Clin J Am Soc Nephrol 3 (2008) 431-436.

[45] P. Gallay, C. Barras, P.S. Tobias, T. Calandra, M.P. Glauser, D. Heumann, Lipopolysaccharide (LPS)-binding protein in human serum determines the tumor necrosis factor response of monocytes to LPS, J Infect Dis 170 (1994) 1319-1322.

[46] E. Hailman, H.S. Lichenstein, M.M. Wurfel, D.S. Miller, D.A. Johnson, M. Kelley, L.A. Busse, M.M. Zukowski, S.D. Wright, Lipopolysaccharide (LPS)-binding protein accelerates the binding of LPS to CD14, J Exp Med 179 (1994) 269-277.

[47] P.S. Tobias, R.J. Ulevitch, Lipopolysaccharide binding protein and CD14 in LPS dependent macrophage activation, Immunobiology 187 (1993) 227-232.

[48] D.P. Funda, L. Tuckova, M.A. Farre, T. Iwase, I. Moro, H. Tlaskalova-Hogenova, CD14 is expressed and released as soluble CD14 by human intestinal epithelial cells in vitro: lipopolysaccharide activation of epithelial cells revisited, Infect Immun 69 (2001) 3772-3781.

[49] V. Bazil, J.L. Strominger, Shedding as a mechanism of down-modulation of CD14 on stimulated human monocytes, J Immunol 147 (1991) 1567-1574.

[50] S. Bas, B.R. Gauthier, U. Spenato, S. Stingelin, C. Gabay, CD14 is an acute-phase protein, J Immunol 172 (2004) 4470-4479.

[51] M.J. Fenton, D.T. Golenbock, LPS-binding proteins and receptors, Journal of leukocyte biology 64 (1998) 25-32.

[52] N. Hiki, D. Berger, M.A. Dentener, Y. Mimura, M.A. Buurman, C. Prigl, M. Seidelmann, E. Tsuji, M. Kaminishi, H.G. Beger, Changes in endotoxin-binding proteins during major elective surgery: Important role for soluble CD14 in regulation of biological activity of systemic endotoxin, Clinical and Diagnostic Laboratory Immunology 6 (1999) 844-850.

[53] H.M. Kim, B.S. Park, J.I. Kim, S.E. Kim, J. Lee, S.C. Oh, P. Enkhbayar, N. Matsushima, H. Lee, O.J. Yoo, J.O. Lee, Crystal structure of the TLR4-MD-2 complex with bound endotoxin antagonist Eritoran, Cell 130 (2007) 906-917.

[54] S.J. van Deventer, H.R. Buller, J.W. ten Cate, L.A. Aarden, C.E. Hack, A. Sturk, Experimental endotoxemia in humans: analysis of cytokine release and coagulation, fibrinolytic, and complement pathways, Blood 76 (1990) 2520-2526.

51 [55] J.E. Tomlinson, A.T. Blikslager, Interactions between lipopolysaccharide and the intestinal epithelium, Journal of the American Veterinary Medical Association 224 (2004) 1446-1452. 
[56] E.B. Eichbaum, H.W. Harris, J.P. Kane, J.H. Rapp, Chylomicrons can inhibit endotoxin activity in vitro, J Surg Res 51 (1991) 413-416.

[57] T.E. Read, C. Grunfeld, Z. Kumwenda, M.C. Calhoun, J.P. Kane, K.R. Feingold, J.H. Rapp, Triglyceride-rich lipoproteins improve survival when given after endotoxin in rats, Surgery 117 (1995) 62-67.

[58] A.C. Vreugdenhil, C.H. Rousseau, T. Hartung, J.W. Greve, C. van 't Veer, W.A. Buurman, Lipopolysaccharide (LPS)-binding protein mediates LPS detoxification by chylomicrons, J Immunol 170 (2003) 1399-1405.

[59] M.M. Wurfel, S.T. Kunitake, H. Lichenstein, J.P. Kane, S.D. Wright, Lipopolysaccharide (LPS)-binding protein is carried on lipoproteins and acts as a cofactor in the neutralization of LPS, The Journal of experimental medicine 180 (1994) 1025-1035. Eichbaum, G.F. Bland, J.H. Rapp, Chylomicrons alter the fate of endotoxin, decreasing tumor necrosis factor release and preventing death, J Clin Invest 91 (1993) 1028-1034.

[61] H.W. Harris, D.C. Rockey, P. Chau, Chylomicrons alter the hepatic distribution and cellular response to endotoxin in rats, Hepatology 27 (1998) 1341-1348.

[62] X.C. Jiang, S. Qin, C. Qiao, K. Kawano, M. Lin, A. Skold, X. Xiao, A.R. Tall, Apolipoprotein B secretion and atherosclerosis are decreased in mice with phospholipid-transfer protein deficiency, Nat Med 7 (2001) 847-852.

[63] T. Gautier, A. Klein, V. Deckert, C. Desrumaux, N. Ogier, A.L. Sberna, C. Paul, N. Le Guern, A. Athias, T. Montange, S. Monier, F. Piard, X.C. Jiang, D. Masson, L. Lagrost, Effect of plasma phospholipid transfer protein deficiency on lethal endotoxemia in mice, J Biol Chem 283 (2008) 18702-18710.

[64] R.S. Munford, Sensing gram-negative bacterial lipopolysaccharides: a human disease determinant?, Infect Immun 76 (2008) 454-465.

[65] H. Huang, T. Liu, J.L. Rose, R.L. Stevens, D.G. Hoyt, Sensitivity of mice to lipopolysaccharide is increased by a high saturated fat and cholesterol diet, J Inflamm (Lond) 4 (2007) 22.

[66] H. Shi, M.V. Kokoeva, K. Inouye, I. Tzameli, H. Yin, J.S. Flier, TLR4 links innate immunity and fatty acid-induced insulin resistance, Journal of Clinical Investigation 116 (2006) 3015-3025.

[67] J.D. Hasday, R. Bascom, J.J. Costa, T. Fitzgerald, W. Dubin, Bacterial endotoxin is an active component of cigarette smoke, Chest 115 (1999) 829-835.

[68] S. Ghoshal, J. Witta, J. Zhong, W. de Villiers, E. Eckhardt, Chylomicrons promote intestinal absorption of lipopolysaccharides, Journal of lipid research 50 (2009) 90-97.

[69] P. Lundman, S. Boquist, A. Samnegard, M. Bennermo, C. Held, C.G. Ericsson, A. Silveira, A. Hamsten, P. Tornvall, A high-fat meat is accompanied by increased plasma interleukin-6 concentrations, Nutrition Metabolism and Cardiovascular Diseases 17 (2007) 195202.

[70] N.N. Mehta, F.C. McGillicuddy, P.D. Anderson, C.C. Hinkle, R. Shah, L. Pruscino, J. Tabita-Martinez, K.F. Sellers, M.R. Rickels, M.P. Reilly, Experimental Endotoxemia Induces Adipose Inflammation and Insulin Resistance in Humans, Diabetes (2009).

[71] M. Lefevre, P.M. Kris-Etherton, G. Zhao, R.P. Tracy, Dietary fatty acids, hemostasis, and cardiovascular disease risk, Journal of the American Dietetic Association 104 (2004) 410-419.

[72] M.C. Michalski, Specific molecular and colloidal structures of milk fat affecting lipolysis, absorption and postprandial lipemia, Eur J Lipid Sci Technol 111 (2009).

[73] H. Singh, A. Ye, D. Horne, Structuring food emulsions in the gastrointestinal tract to modify lipid digestion, Progress in Lipid Research (2009).

[74] H.L. Mu, C.E. Hoy, The digestion of dietary triacylglycerols, Progress in Lipid Research 43 (2004) 105-133.

[75] M. Armand, Lipases and lipolysis in the human digestive tract: where do we stand?, Curr.Opin.Clin.Nutr.Metab.Care 10 (2007) 156-164. 
[76] N. Miled, S. Canaan, L. Dupuis, A. Roussel, M. RiviŠre, F. CarriŠre, A. de Caro, C. Cambillau, R. Verger, Digestive lipases - from three dimensional structure to physiology, Biochimie 82 (2000) 973-986.

[77] V. Petit, I. Niot, H. Poirier, P. Besnard, Absorption intestinale des acides gras: faits et incertitudes, Nutrition Clinique et M,tabolisme 21 (2007) 38-45.

[78] I. Garaiova, I.A. Guschina, S.F. Plummer, J. Tang, D. Wang, N.T. Plummer, A randomised cross-over trial in healthy adults indicating improved absorption of omega-3 fatty acids by pre-emulsification, Nutrition Journal 6 (2008) 4-13.

[79] N. Mekki, M. Charbonnier, P. Borel, J. Leonardi, C. Juhel, H. Portugal, D. Lairon, Butter differs from olive oil and sunflower oil in its effect on postprandial lipemia and triacylglycerolrich lipoproteins after single mixed meals in healthy young men, J.Nutr. 132 (2002) 3642-3649.

[80] S.E.E. Berry, T.A.B. Sanders, Influence of triacylglycerol structure of stearic-rich fats on postprandial lipemia, Proceedings of the Nutrition Society 64 (2005) 205-212.

[81] D.M. Robinson, N.C. Martin, L.E. Robinson, I. Ahmadi, A.G. Marangoni, A.J. Wright, Influence of Interesterification of a Stearic Acid-Rich Spreadable Fat on Acute Metabolic Risk Factors, Lipids (2009).

[82] J.K. Lorenzen, S. Nielsen, J.J. Holst, I. Tetens, J.F. Rehfeld, A. Astrup, Effect of dairy calcium or supplementary calcium intake on postprandial fat metabolism, appetite, and subsequent energy intake, American Journal of Clinical Nutrition 85 (2007) 678-687.

[83] N. Boon, G.B. Hul, J.H. Stegen, W.E. Sluijsmans, C. Walle, D. Langin, N. Viguerie, W.H. Sarris, An intervention study of the effects of calcium intake on faecal fat excretion, energy metabolism and adipose tissue mRNA expression of lipid-metabolism related proteins, International Journal of Obesity 31 (2007) 1704-1712.

[84] N.T. Bendsen, A.L. Hother, S.K. Jensen, J.K. Lorenzen, A. Astrup, Effect of dairy calcium on fecal fat excretion: a randomized crossover trial, International Journal of Obesity (2009).

[85] S.E.E. Berry, G.J. Miller, T.A.B. Sanders, The solid fat content of stearic acid-rich fats determines their postprandial effects, American Journal of Clinical Nutrition 85 (2007) 14861494.

[86] L. Bonnaire, S. Sandra, T. Helgason, E.A. Decker, J. Weiss, D.J. McClements, Influence of lipid physical state on the in vitro digestibility of emulsified lipids, Journal of Agricultural and Food Chemistry 56 (2009) 3791-3797.

[87] P. Borel, M. Armand, B. Pasquier, M. Senft, G. Dutot, C. Melin, H. Lafont, D. Lairon, Digestion and absorption of tube-feeding emulsions with different droplet sizes and compositions in the rat, J.Parenteral Enteral Nutr. 18 (1994) 534-543.

[88] P. Borel, M. Armand, P. Ythier, G. Dutot, C. Melin, M. Senft, H. Lafont, D. Lairon, Hydrolysis of emulsions with different triglycerides and droplet sizes by gastric lipase in vitro. Effect on pancreatic lipase activity, Journal of Nutritional Biochemistry 5 (1994) 124-133.

[89] G. Favé, T.C. Coste, M. Armand, Physicochemical properties of lipids: new strategies to manage fatty acid bioavailability, Cell.Mol.Biol. 50 (2004) 815-831.

[90] S. Mun, E.A. Decker, D.J. McClements, Influence of emulsifier type on in vitro digestibility of lipid droplets by pancreatic lipase, Food Research International 40 (2007) 770-781. [91] G. Clemente, M. Mancini, F. Nazzaro, G. Lasorella, A. Rivieccio, A.M. Palumbo, A.A. Rivellese, L. Ferrara, R. Giacco, Effect of different dairy products on postprandial lipemia, Nutr.Metab.Cardiovasc.Dis. 13 (2003) 377-383.

[92] K.M. Sanggaard, J.J. Holst, J.F. Rehfeld, B. Sandstrom, A. Raben, T. Tholstrup, Different effects of whole milk and a fermented milk with the same fat and lactose content on gastric emptying and postprandial lipaemia, but not on glycaemic response and appetite, British Journal of Nutrition 92 (2004) 447-459.

[93] T. Tholstrup, C.E. H $\square$ y, L. Normann Andersen, R.D.K. Christensen, B. Sandstr"m, Does fat in milk, butter and cheese affect blood lipids and cholesterol differently?, J.Am.Coll.Nutr. 23 (2005) 169-176. 
1 [94] M.C. Michalski, V. Briard, M. Desage, A. Geloen, The dispersion state of milk fat 2 influences triglyceride metabolism in the rat - A (CO2)-C-13 breath test study, European Journal 3 of Nutrition 44 (2005) 436-444.

4 [95] M.C. Michalski, A.F. Soares, C. Lopez, N. Leconte, V. Briard, A. Geloen, The supramolecular structure of milk fat influences plasma triacylglycerols and fatty acid profile in the rat, European Journal of Nutrition 45 (2006) 215-224.

[96] M.C. Michalski, On the supposed influence of milk homogenization on the risk of CVD, diabetes and allergy, British Journal of Nutrition 97 (2007) 598-610.

9 [97] M.C. Michalski, C. Januel, Does homogenization affect the human health properties of cow's milk?, Trends in Food Science \& Technology 17 (2006) 423-437.

[98] H. Kono, H. Fujii, M. Asakawa, M. Yamamoto, M. Matsuda, A. Maki, Y. Matsumoto, Protective effects of medium-chain triglycerides on the liver and gut in rats administered endotoxin, Annals of surgery 237 (2003) 246-255.

[99] D.M. Small, The effects of glyceride structure on absorption and metabolism, Annu.Rev.Nutr. 11 (1991) 413-434.

[100] S. Wein, S. Wolffram, J. Schrezenmeir, D. Gasperikova, I. Klimes, E. Seb"kova, Mediumchain fatty acids ameliorate insulin resistance caused by high-fat diets in rats, Diabetes Metab.Res.Rev. 25 (2009) 185-194.

[101] E. Wat, S. Tandy, E. Kapera, A. Kamili, R.W. Chung, A. Brown, M. Rowney, J.S. Cohn, Dietary phospholipid-rich dairy milk extract reduces hepatomegaly, hepatic steatosis and hyperlipidemia in mice fed a high-fat diet, Atherosclerosis (2009). 


\section{Figure caption}

2 Figure 1. (A) Typical structure of bacterial endotoxins (lipopolysaccharides, LPS). (B)

3 Proinflammatory cascade induced by LPS.

4 LBP: Lipopolysaccharide-binding protein; mCD14: membrane cluster of differentiation 14;

5 TLR4: toll-like receptor 4; MD2: myeloid differentiation protein-2; NFkB: nuclear factor kB; IL6:

6 interleukin-6 (inflammatory cytokine).

8 Figure 2. (A) Digestion of a mixed breakfast with $33 \mathrm{~g}$ lipids induces postprandial increase in

9 plasma LPS, sCD14 and IL-6 in healthy humans; LPS being partly adsorbed onto chylomicrons

10 (adapted from Laugerette et al. [9]).

11 (B) Postprandial endotoxin accumulation (AUC of endotoxemia during $6 \mathrm{~h}$ of digestion) depends

12 on dietary fat presence and emulsification state in force fed lean rats (adapted from Laugerette et 13 al. [9]).

15 Figure 3. Possible impact of dietary lipids on postprandial lipid and LPS absorption and metabolic 16 outcomes.

17 Obesity and Type 2 Diabetes are characterized by altered profile of intestinal microbiota and by 18 altered lipid metabolism.

19 During lipid digestion, endotoxins from microbiota are absorbed along with lipids and can be 20 vehicled by chylomicrons.

21 In a healthy pattern, lipids are mostly oxidized and endotoxins are cleared by the liver.

22 In a metabolic dysfunction pattern (obesity, type 2 diabetes), lipids are more oriented towards 23 storage in the adipose tissue and more circulating endotoxins contribute to generate low-grade 24 inflammation. 